\title{
Bimbingan Kelompok dengan Teknik Sinema Edukasi Untuk Meningkatkan Kesadaran Multikultural Siswa Kelas XI Di SMA Isen Mulang Palangka Raya
}

\author{
Ira Iryani', Mimi Suriatie ${ }^{2}$ \\ Prodi BK FKIP Universitas Palangka Raya \\ E-mail: 'irairyani97@yahoo.com
}

\begin{abstract}
ABSTRAK
Kesadaran multikultural merupakan kemampuan seseorang untuk melihat ke luar dirinya sendiri dan menyadari akan nilainilai budaya, kebiasaan budaya yang masuk. Penelitian ini bertujuan menghasilkan model bimbingan kelompok dengan teknik sinema edukasi untuk meningkatkan kesadaran multikultural. Model yang dikembangkan, dinyatakan layak digunakan berdasarkan validasi oleh ahli dan ujicoba kepada siswa SMA Isen Mulang Palangka Raya. Penelitian ini merupakan jenis penelitian pengembangan. Tahapan yang dilakukan untuk menghasilkan model bimbingan kelompok dengan teknik sinema edukasi sebagai berikut : a) tahap pengumpulan informasi; b) tahap perencanaan; c) tahap pengembangan; d) tahap validasi dan ujicoba. Teknik pengumpulan data dilakukan dengan wawancara, observasi, dan kuesioner. Populasi penelitian ini berjumlah 30 siswa kelas XI SMA Isen Mulang Palangka Raya, sampel yang diambil berjumlah 8 orang yang ditentukan dengan menggunakan teknik purposive sampling. Hasil penelitian menunjukan bahwa pada penilaian validasi ahli, dapat diketahui skor berjumlah 80 , rata-rata skor 3,6, rentang skor $60.00<X \leq 79.00$ dalam kategori baik. Uji coba kelompok kecil pre-test I 288 dalam kategori rendah dan post-test 1467 dikategorikan tinggi. Hasil uji hipotesis taraf kepercayaan $\alpha=5 \%$ dengan $\mathrm{dk}=8-\mathrm{I}$ diperoleh $\mathrm{t}$ table $=2.262$. Besarnya nilai $\mathrm{t}$ hitung $=10.232 \geq$ harga $\mathrm{t}$ table; $5 \%$ yakni 2.262 . Dengan demikian, model bimbingan kelompok dengan teknik sinema edukasi dapat meningkatkan kesadaran multikultural siswa kelas XI SMA Isen Mulang Palangka Raya.
\end{abstract}

Kata Kunci: Kesadaran Multikultural; Teknik Sinema Edukasi; Bimbingan Kelompok

\section{Group Guidance with Educational Cinema Techniques to Increase Multicultural Awareness Students in Class XI SMA Isen Mulang Palangka Raya}

\begin{abstract}
Multicultural awareness is a person's ability to look outside himself and be aware of cultural values, cultural habits that enter. This study aims to produce a group guidance model with educational cinema techniques to increase multicultural awareness. The developed model was declared suitable for use based on validation by experts and trials to students of SMA Isen Mulang Palangka Raya. This research is a type of development research. The steps taken to produce a group guidance model with educational cinema techniques are as follows: a) information gathering stage; b) planning stage; c) development stage; d) validation and trial phase. Data collection techniques were carried out by interviews, observations, and questionnaires. The population of this study amounted to 30 students of class XI SMA Isen Mulang Palangka Raya, the samples taken were 8 people who were determined using purposive sampling technique. The results showed that in the expert validation assessment, it can be seen that the score is 80 , the average score is 3.6, the score range is $60.00<X 79.00$ in the good category. The small group trial of I 288 pre-test in the low category and the post-test 1467 in the high category. The results of hypothesis testing with a confidence level of $=5 \%$ with dk $=8-I$ obtained $t$ table $=2.262$. The value of $t$ count $=10.232$ the value of $t$ table; $5 \%$ which is 2,262 . Thus, the group guidance model with educational cinema techniques can increase the multicultural awareness of class XI students of SMA Isen Mulang Palangka Raya.
\end{abstract}

Keywords: Multicultural Awareness; Educational Cinema Techniques; Guidanve Group 


\section{PENDAHULUAN}

Budaya merupakan istilah yang banyak dijumpai dan digunakan hampir setiap aktivitas sehari-hari. Hal ini menunjukkan bahwa budaya begitu dekat dengan lingkungan kita. Kata budaya dipandang penting karena kata ini membentuk dan merupakan bagian dari istilah dari pendidikan multikultural. Bagaimana kita mendefinisikan budaya akan menentukan arti dari istilah pendidikan multikultural. Tanpa mengetahui apa arti budaya, kita akan sulit memahami implikasi pendidikan multikultural secara utuh. Misalnya, jika budaya didefinisikan sebagai warisan dan tradisi dari suatu kelompok sosial, maka pendidikan multikultural berarti mempelajari tentang berbagai warisan dan tradisi budaya. Namun jika budaya didefinisikan sebagai desain kelompok sosial untuk bertahan hidup dan beradaptasi dengan lingkungannya, maka satu tujuan pendidikan multikultural adalah untuk mempelajari tentang berbagai kelompok sosial dan desain yang berbeda untuk hidup dalam masyarakat yang pluralis (Bullivant dalam Murdiono, 20I2). Budaya banyak dijumpai dan digunakan hampir setiap aktivitas sehari-hari, dan di lingkungan kita khususnya di Provinsi Kalimantan ini ditempati oleh masyarakat yang berbeda-beda budayanya, terlihat di sekolahsekolah banyak siswa yang berbeda-beda budayanya, maka dari itu sangat penting untuk siswa dalam mengetahui pentingnya mempelajari Multikurtural, agar bisa memahami pentingnya untuk mengetahui budaya selain budaya yang mereka miliki.

Menurut Rahmatullah (dalam Rasimin, 2016) multikultural dalam bahasa Arab disebut tasamuh yang berarti suatu sikap menerima pihak lain dan menghargai perbedaan. Multikultural dalam kehidupan bermasyarakat berbangasa dan bernegara terdapat empat makna, yaitu: a) merasa senasib sepenanggungan; b) menciptakan persatuan dan kesatuan, rasa kebangsaan atau nasionalisme; c) mengakui dan menghargai hak asasi manusia; dan d) tidak menjelek-jelekan kebudayaan, suku, adat istiadat orang lain.

Pendidikan multikultural adalah proses pendidikan yang tujuan utamanya adalah untuk mengubah struktur lembaga pendidikan supaya siswa, baik pria maupun wanita, siswa berkebutuhan khusus, dan siswa yang merupakan anggota dari kelompok ras, etnis, dan budaya yang bermacam-macam itu akan memiliki kesempatan yang sama untuk mencapai prestasi akademis di sekolah. Salah satu dasar dari pendidikan multikultural adalah kesadaran nilai penting keragaman budaya. Maka dari itu sangat penting untuk meningkatkan kesadaran budaya siswa. Sering kali dijumpai permasalahan yang berhubungan dengan budaya, seperti adanya diskriminasi antara sesama siswa, dikarenakan perbedaan ras, agama, ataupun sosial. Masalah yang terlihat saat ini mengenai kesadaran tentang budaya pada anak sekolahan khususnya di SMA Isen Mulang yaitu banyak siswa yang kurang memahami akan keberagaman budaya, kurang menghargai budaya selain budaya mereka sendiri, bahkan ada yang kurang peduli akan budayanya sendiri, terlihat dari hasil obervasi dilapangan, ketika guru seni budaya memberikan tugas untuk mencari adat istiadat dari budaya lain selain budaya mereka sendiri mereka terlihat kebingungan dan banyak yang mengeluh. Dari fenomena tersebut terlihat bahwa kurangnya kesadaran budaya yang dimiliki siswa. Mereka enggan untuk mempelajari budaya lainselain budaya mereka sendiri. Selain itu ketika guru BK membagikan kelompok untuk kelompok belajar, ada siswa yang berkata bahwa dia ingin satu kelompok dengan teman satu geng/kelompoknya, dia tidak ingin satu kelompok dengan teman yang lainnya. Ternyata bukan hanya 
Ira Iryani', Merson U. Sangalang ${ }^{2}$, Mimi Suriatie $^{3}$ Jurnal Bimbingan dan Konseling Pandohop Volume I, Nomor 2, Tahun 2021 e-ISSN 2775-5509

didalam kelas diluar kelas pun mereka tetap bergelombol dengan teman yang sukunya sama. Dari hasil observasi dikelas terlihat ada beberapa siswa melakukan buliying terhadap siswa yang memiliki kulit warna hitam dan logat bahasanya yang khas, mereka menjadikannya bahan olokan. Untuk menanggulangi permasalahan tersebut Sekolah selama ini memberikan layanan informasi biasa, hanya sebatas memberi nasihat saja, tidak ada pelatihan maupun bimbingan intensif.

Sekolah telah mengupayakan untuk memberikan kesadaran multikultural di SMA Isen Mulang Palangka Raya dengan melaksanakan kegiatan layanan bimbingan kelompok dengan tema-tema sosial. Sukardi (dalam Futri, 202I) menjelaskan bahwa Layanan bimbingan kelompok adalah layanan yang memungkinkan sejumlah siswa secara bersama-sama memperoleh bahan dari narasumber tertentu (terutama guru pembimbing atau konselor) yang berguna untuk menunjang kehidupan sehari-hari baik individu sebagai pelajar, anggota keluarga, dan masyarakat serta untuk mempertimbangkan dalam pengambilan keputusan. Bimbingan kelompok berfungsi untuk upaya pencegahan (preventif), pemahaman serta pengembangan khususnya pada perkembangan sosial siswa terutama pada kesadaran multikultural. Akan tetapi pelaksanaan layanan bimbingan kelompok yang diberikan dilakukan oleh konselor belum efektif, karena dilakukan dengan metode yang monoton seperti memberikan nasehat atau ceramah saja yang membuat siswa kurang berminat dan kurang antusias yang berujung pada ketidakefetifan layanan tersebut.

Mandison \& Schmidt (dalam Hidayah, 2016) menyebutkan bahwa mendidkusikan suatu masalah dengan menggunakan salah satu karakter dalam film, kemungkinan akan meredakan ketegangan ketika membahas topik-topik pribadi yang lebih sensitif secara langsung. Fischoff \& Stuart (dalam Hidayah, 2016) menyatakan bahwa film dapat mempengaruhi cara pandang dan mengubah sikap seseorang. Oleh karena efek dari sebuah film sangat kuat karena pengaruh sinergis musik, dialog, lighting (pencahayaan), sudut pengambilan gambar, dan sound effect (efek suara) memungkinkan film untuk melewati defensive cencors (sensor pertahanan) di dalam diri individu.

Pendapat yang disampaikan oleh beberapa ahli tersebut menunjukkan bahwa film atau sinema merupakan salah satu teknik yang dapat digunakan untuk mengubah cara padang seseorang dan mengembangkan perilaku positif dari sebuah film atau sinema. Film dapat mengubah persepsi dan cara pandang seseorang mengenai suatu hal yang nyata dan karakter dalam film dapat memberikan inspirasi dan motivasi bagi seseorang dalam menyikapi kehidupannya. Melalui film, seseorang akan memiliki pengalaman dan wawasan yang akan diterapkan dalam kehidupan sehari-hari. Menurut Alexander \& Waxma (dalam Hidayah, 2016) menegaskan bahwa keefektifan sinema edukasi melalui pemutaran film bermakna untuk merangsang kesadaran diri. Teknik sinema edukasi dalam layanan bimbingan kelompok digunakan untuk merangsang siswa mengambil hikmah dari isi cerita dan karakter yang diperankan dalam sinema tersebut. Melalui tayangan cuplikan film, siswa akan lebih mudah menagkap pesan-pesan yang disampaikan dalam sinema. Karena remaja jaman sekarang lebih sering melakukan kegiatan yang bersifat visual di luar sekolah seperti menonton. Sebagai contoh, dalam sehari seorang remaja dan dewasa menghabiskan waktu lebih dari 3 jam hanya untuk menonton film, video youtube, dll. Dari fenomena tersebut dapat disimpulkan bahwa aktivitas audio visual memiliki daya tarik yang besar sebagai suatu media, baik untuk 
pembelajaran maupun penyebar informasi, sehingga masih sangat diminati oleh setiap kalangan.

Dengan kemajuan jaman yang semakin canggih, kita bisa menyampaikan suatu informasi dengan mudah, kita bisa memanfaatkan kegemaran remaja jaman sekarang yang lebih menyukai kegiatan yang berhubungan dengan visualisasi seperti menonton, maka dari itu kita bisa menggunakan teknik sinema edukasi untuk meningkatkan kesadaran multikultural siswa, dengan begitu diharapkan siswa bisa dengan mudah memahami apa yang ingin kita sampaikan dan mereka bisa mengaplikasikannya dalam kehidupan mereka sehari-hari. Maka dari itu peneliti ingin membuat panduan bimbingan kelompok dengan teknik sinema edukasi untuk meningkatkan kesadaran multikultural siswa. Sinema edukasi adalah teknik bimbingan dengan menggunakan media atau video yang berkaitan dengan unsur pembelajaran yang akan menjadi metode dalam pelaksanaan bimbingan kelompok.

\section{METODOLOGI}

Tempat penelitian dilaksanakan di SMA Isen Mulang Palangka Raya. Penyusunan dari skripsi penelitian ini selama 6 bulan dimulai dari bulan Juni 2019 sampai dengan bulan November 2019. Teknik pengambilan sampel dalam penelitian ini dilakukan dengan purposive sampling yaitu teknik penentuan sampel dengan pertimbangan tertentu.

Penelitian ini merupakan jenis penelitian pengembangan. Pengembangan yang dimaksud adalah pembuatan penilaian (sikap, proses, pengetahuan dan keterampilan dalam bentuk penilaian tertulis) pada kesadaran multikultural siswa. Diharapkan penilaian yang dihasilkan dapat digunakan sebagai evaluasi dalam pembelajaran dan dapat menilai hasil pembelajaran

secara objektif melalui penerapan pendekatan saintifik. Menurut Sugiyono (2018) penelitian dan pengembangan adalah metode penelitian yang digunakan untuk menghasilkan produk tertentu, dan menguji keefektifan produk tersebut. Sukmadinata (Sukmadinata, 2019) mendefinisikan penelitian dan pengembangan merupakan pendekatan penelitian untuk menghasilkan produk baru atau menyempurnakan produk yang telah ada. Jadi penelitian pengembangan merupakan metode untuk menghasilkan produk tertentu atau menyempurnakan produk yang telah ada serta menguji keefektifan produk tesebut.

Tingkat pengembangan model bimbingan kelompok dengan teknik sinema edukasi untuk meningkatkan kesadaran multikultural melalui validasi oleh ahli dan uji coba kepada siswa. Penelitian pengembangan ini mengacu pada model pengembangan yang dibatasi pada beberapa tahap saja. Tahap-tahap tersebut meliputi: a) Tahap pengumpulan informasi; b). Tahap perencanaan; c). Tahap pengembangan produk; dan d). Tahap validasi dan ujicoba. Teknik Pengumpulan data yang digunakan dalam penelitian ini yaitu: Angket, Observasi dan Dokumentasi. Instrument Penelitian yang digunakan dalam penelitian ini adalah angket skala kesadaran multikultural. Angket dalam penelitian ini menggunakan model likert. Model skala likert biasanya terdiri dari 5 jawaban. Teknik analisis data yang digunakan dalam penelitian ini adalah statistik deskriptif. “ statistik deskriptif merupakan statistik yang digunakan untuk menganalisis data dengan mendeskripsikan atau menggambarkan data yang terkumpul sesuai dengan fakta tanpa membuat kesimpulan yang berlaku untuk umum" (Sugiyono, 2018). 
Ira Iryani', Merson U. Sangalang ${ }^{2}$, Mimi Suriatie $^{3}$ Jurnal Bimbingan dan Konseling Pandohop Volume I, Nomor 2, Tahun 2021 e-ISSN 2775-5509

\section{HASIL DAN PEMBAHASAN}

Penelitian dan pengembangan ini bertujuan untuk menghasilkan model bimbingan kelompok dengan teknik sinema edukasi untuk meningkatkan kesadaran multikultural. Model yang dikembangkan, dinyatakan layak digunakan berdasarkan validasi oleh ahli materi dan ujicoba siswa. Penelitian pengembangan ini mengacu pada model pengembangan yang dibatasi pada beberapa tahap saja. Tahap-tahap tersebut meliputi: a) Tahap pengumpulan informasi; b). Tahap perencanaan; c). Tahap pengembangan produk; dan d). Tahap validasi dan ujicoba.

Hasil validasi oleh ahli materi dilakukan untuk memperoleh data kelayakan sumber model dari aspek materi. Tujuan dari validasi ini, untuk mendapatkan informasi, kritik, dan saran dari ahli materi sehingga sumber belajar yang dihasilkan dapat berkualitas dari segi materi. Validasi dilakukan oleh Bapak Merson U sangalang, beliau merupakan salah satu dosen Bimbingan dan Konseling yang berkompeten mengajarkan konseling lintas budaya. Data yang diambil pada validasi materi menitikberatkan pada beberapa aspek, diantaranya kesesuaian materi dengan $\mathrm{KI}$ dan KD, keakuratan materi, materi pendukung pembelajaran, dan ketepatan penyajian materi.

Sedangkan hasil ujicoba siswa digunakan untuk mengetahui tanggapan siswa terhadap sumber belajar melalui angket. Jumlah indikator dalam angket 5 . Uji coba dilakukan terhadap 30 siswa. Jumlah skor yang diperoleh adalah I5I,06 dengan rata-rata 4,9.

Tabel I. Hasil Tanggapan siswa

\begin{tabular}{ccccc}
\hline $\begin{array}{c}\text { Jumlah } \\
\text { Skor }\end{array}$ & Rata- & Rata- & Rentang & Kategori \\
& rata & rata & skor & \\
& & Skor & & \\
\hline I5I,06 & 4,9 & $>4,2$ & $67,00 \times>$ & Sangat Baik \\
& & & 83,00 &
\end{tabular}

Selain itu untuk menentukan kriteria kesadaran multikultural, maka masing-masing skor pada setiap responden dimasukkan dalam interval pengkategorian dengan rumus :

Interval = skor tertinggi - skor terendah / kategori

Kategori : Sangat Sesuai, Sesuai, Kurang Sesuai, Sangat Tidak Sesuai

Berdasarkan rumus interval tersebut dapat digunakan untuk membuat tabel distribusi frekuensi bergolong sesuai dengan kategori jawaban instrumen penilaian kesadaran multikultural yang diisi oleh 30 responden kemudian diambil sampel sebanyak 8 orang dengan menggunakan teknik Purposive Sampling.

Tabel 3. Skor Hasil Penilaian Instrumen Kesadaran Multikultural Sebelum dan Sesudah Pemberian Layanan Bimbingan Kelompok.

\begin{tabular}{|c|c|c|c|c|c|c|}
\hline \multirow{2}{*}{ No } & \multicolumn{2}{|c|}{ Total Skor } & \multirow{2}{*}{ d } & \multirow{2}{*}{$d^{\wedge} 2$} & \multicolumn{2}{|c|}{ kategori } \\
\hline & Pre & Post & & & Pre & Post \\
\hline I & 150 & 186 & 36 & 1296 & Sedang & Tinggi \\
\hline 2 & 174 & 192 & 18 & 324 & Sedang & Tinggi \\
\hline 3 & 162 & 187 & 25 & 625 & Sedang & Tinggi \\
\hline 4 & 168 & 185 & 17 & 289 & Sedang & Tinggi \\
\hline 5 & 161 & 180 & 19 & 361 & Sedang & Tinggi \\
\hline 6 & 156 & 180 & 24 & 576 & Sedang & Tinggi \\
\hline 7 & 152 & 173 & 21 & 441 & Sedang & Tinggi \\
\hline 8 & 165 & 184 & 19 & 361 & Sedang & Tinggi \\
\hline Total & I 288 & 1467 & 179 & 4273 & & \\
\hline Mean & 161 & 183,4 & 22,4 & 1068 & & \\
\hline
\end{tabular}

Berdasarkan hasil penelitian dengan menggunakan instrumen kesadaran multikultural bahwa kesadaran multikultural siswa sebelum dan sesudah layanan bimbingan kelompok menunjukkan kemajuan yang baik, hal ini dapat dilihat pada kesadaran multikultural pre-test I skor yang diperoleh hanya sebesar I 288 dan dikategorikan memiliki kesadaran multikultural sedang dalam berinteraksi budaya dan sosial, setelah diberikan layanan bimbingan kelompok terdapat 
Ira Iryani', Merson U. Sangalang ${ }^{2}$, Mimi Suriatie $^{3}$ Jurnal Bimbingan dan Konseling Pandohop Volume I, Nomor 2, Tahun 2021 e-ISSN 2775-5509

perubahan skor meningkat 29,95\% (post-test I) menjadi 1467 dan dikategorikan memiliki kesadaran multikultural yang tinggi.

Berdasarkan data yang terkumpul baik dari hasil instrumen penilaian kesadaran multikultural sebelum layanan bimbingan kelompok dengan teknik psikoedukasi keterampilan hidup dan setelah mendapatkan layanan bimbingan kelompok, langkah selanjutnya adalah menganalisa data dengan menggunakan rumus uji t-test. Data diperoleh varian beda $\sum x^{2} d$ kesadaran multikultural sebesar 267,875. Maka penghitungan uji-t taraf kepercayaan $\alpha=5 \%$ dengan $\mathrm{dk}=8-\mathrm{I}$ diperoleh $\mathrm{t}$ table $=2,262$. Besarnya $\mathrm{t}$ hitung $=10,232$ melebihi harga $\mathrm{t}$ table; $5 \%$ yakni 2,262. Dapat disimpulkan bahwa data kesadaran multikultural signifikan dan hipotesis penelitian (ha) dapat diterima.

\section{KESIMPULAN}

Berdasarkan hasil penelitian dan pengembangan model bimbingan kelompok dengan teknik sinema edukasi untuk meningkatkan kesadaran multikultural siswa kelas XI SMA Isen Mulang Palangka Raya dilakukan melalui beberapa tahap yaitu tahap pembukaan, peralihan, kegiatan dan pengakhiran. Adapun uji efektifitas bimbingan kelompok dengan teknik sinema edukasi untuk meningkatkan kesadaran multikultural siswa dilakukan dengan membandingkan hasil pre-test dan post test angket yang diberikan kepada siswa. Melalui hasil perhitungan uji perhitungan t-test dapat disimpulkan bahwa bimbingan kelompok dengan teknik sinema edukasi efektif untuk meningkatkan kesadaran multikultural bahwa kesadaran multikultural siswa di SMA Isen Mulang Palangka Raya. Peneliti berharap untuk peneliti selanjutnya dapat mengembangkan teknik sinema edukasi sebagai alat intervensi untuk meningkatkan permasalahanpermasalahan sosial lainnya.

\section{REFERENSI}

FUTRI, D. (202I). PENGARUH KONSELING KELOMPOK TEKNIK ASSERTIVE TRAINING UNTUK MENINGKATKAN KONSEP DIRI REMAJA SMA DI JORONG TABING NAGARI. https://repo.iainbatusangkar.ac.id/xmlui/handle/ I 23456789/2। 105

Hidayah. (2016). Keefektifan Teknik Sinema Edukasi untuk Meningkatkan Sikap Asertif Siswa MTs Negeri Malang I. Jurnal Pendidikan Dan Pembelajaran, 165. http://journal.um.ac.id/index.php/pendidikandan-pembelajaran/article/view/7528

Murdiono, M. (2012). Strategi Pembelajaran Pendidikan Multikultural Berbasis Budaya Lokal. https://jurnal.fkip.uns.ac.id/index.php/progresif/a rticle/view/2232

Rasimin. (2016). Pengembangan Karakter Multikultural Mahasiswa dalam Pembelajaran Civic Education (Studi pada Mahasiswa Jurusan Kpi Fakultas Dakwah lain Salatiga). Interdisciplinary Journal of Communication. https://www.ijtihad.iainsalatiga.ac.id/index.php/l NJECT/article/view/645

Sugiyono. (2018). Metode Penelitian Kuantitatif,Kualitatif dan R\&D. In ke-26.

Sukmadinata, N. (2019). Metode penelitian pendidikan. http://www.litbang.kemkes.go.id:8080/handle//2 $3456789 / 61238$ 